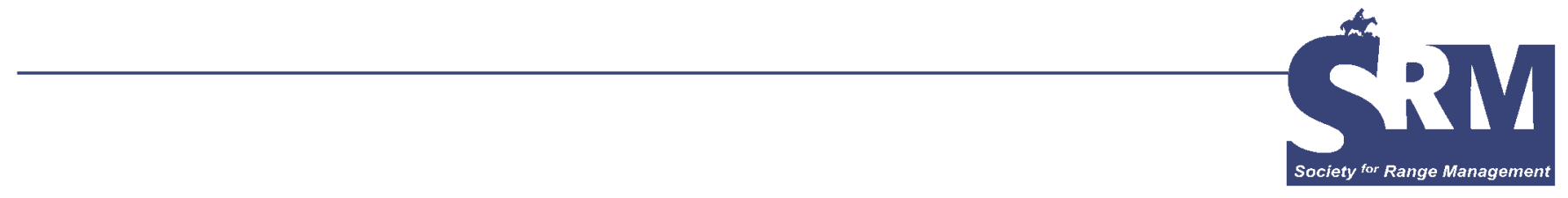

\title{
A Sporting Alternative
}

\section{Sport cattle may help cattle growers round up their profits.}

\section{By Jerry M. Hawkes, Jay M. Lillywhite, and James D. Libbin}

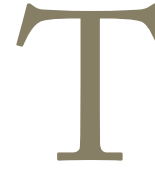

here's no question that sport is big business in North America and now cattle growers have a chance to get into the game by supplying animals for the competitive roping and rodeo events that have been rapidly increasing in popularity in recent years. ${ }^{1}$ The United States Team Roping Championships, Inc., which sponsors team roping events, has more than 100,000 members and estimates that nearly 1.5 million individuals participated in team roping in the United States in 2004. ${ }^{2}$ The Professional Rodeo Cowboys Association (PRCA) sanctions 750-800 annual rodeos attended by nearly 20 million spectators and watched by millions more on ESPN and TNN. The National Finals Rodeo (NFR) is attended by 170,000 spectators every December in Las Vegas. The National High School Rodeo Association is one of the fastest growing youth organizations in the nation, with an annual membership of more than 10,500 students from 40 states, 5 Canadian provinces, and Australia. It sanctions more than 1,100 rodeos each year. Overall, rodeo attracted 24 million spectators in 2004 , placing it seventh overall in total spectators at any one sport. ${ }^{3}$ Not all people who compete and use sport cattle will belong to these large, organized associations. In addition, there are many smaller, local groups that contribute to the market for sport cattle. These participants and spectators are hooked on sports that in 2004 required an estimated 35,000 head of cattle.

This article has been peer reviewed.

\section{Cattle as Sporting Goods}

Considering cattle as "recreational goods" raises their price on a per unit basis. In the world of economics, recreational goods have what economists call an "inelastic demand function." ${ }^{\prime}$ That essentially means that even when the price goes up, people keep buying. When it comes to sporting events that rely on cattle, participants and spectators alike consider related expenses as "necessary" and not an "extra." Even when their disposable incomes go down, these items are not eliminated from their budgets. The good news is that disposable incomes in the United States have risen substantially in the past several decades. According to the US Bureau of Economic Analysis, in 1970, the disposable income of the average American was $\$ 3,600$. In 2003 , it had risen to $\$ 27,275$. Adjusted for inflation, this is a $6.3 \%$ annual rate of increase.

Feeding demand on the participant side is the prize money. The NFR alone offers more than $\$ 2$ million in prize money. The PRCA offers $\$ 22$ million in prize money annually. The US Team Roping Championships presented more than $\$ 16$ million in prize money in 2003. ${ }^{6}$ Team roping and rodeo competitors maintain the idea that they will win money while being involved in these recreation events, just like gamblers who always expect to win.

\section{Beefing up the Bottom Line?}

The major sport cattle sellers say that Corriente is the breed of choice for roping and steer wrestling. They are preferred by ropers and wrestlers because of their longevity, size, and durability. Corriente cattle can be traced to 1493 when the Span- 
Table 1. Production costs and returns for stocker cattle and sport cattle raised in the United States and sport cattle raised in Mexico, 1994-2003.

\begin{tabular}{|c|c|c|c|c|c|c|}
\hline \multirow{3}{*}{ Purchased steers } & \multicolumn{2}{|c|}{ US beef cattle } & \multicolumn{2}{|c|}{ US sport cattle } & \multicolumn{2}{|c|}{ Mexican sport cattle } \\
\hline & \multicolumn{2}{|r|}{ Value/unit } & \multicolumn{2}{|r|}{ Value/unit } & \multicolumn{2}{|r|}{ Value/unit } \\
\hline & 350 & $\$ 301.55$ & 350 & $\$ 257.73$ & 350 & $\$ 216.49$ \\
\hline Death loss & $3 \%$ & $\$ 0.00$ & $3 \%$ & $\$ 0.00$ & $3 \%$ & $\$ 0.00$ \\
\hline Animals sold & 340 & $\$ 0.00$ & 340 & $\$ 0.00$ & 340 & $\$ 0.00$ \\
\hline Salt and minerals & 7 & $\$ 4.74$ & 3 & $\$ 1.63$ & 4 & $\$ 2.18$ \\
\hline $\begin{array}{l}\text { Protein supplementa- } \\
\text { tion }\end{array}$ & 34 & $\$ 26.24$ & 12 & 8.10 & 12 & $\$ 7.95$ \\
\hline Vet and medicine & Per head & $\$ 13.00$ & & $\$ 13.00$ & & $\$ 8.50$ \\
\hline Livestock hauling & Per head & $\$ 4.50$ & & $\$ 4.50$ & & $\$ 3.00$ \\
\hline Hired labor & Per head & $\$ 35.35$ & & $\$ 29.46$ & & $\$ 22.09$ \\
\hline $\begin{array}{l}\text { Equipment operating } \\
\text { costs }\end{array}$ & Per head & $\$ 13.25$ & & $\$ 11.78$ & & $\$ 2.95$ \\
\hline $\begin{array}{l}\text { Vehicle operating } \\
\text { coasts }\end{array}$ & Per head & $\$ 22.09$ & & $\$ 17.67$ & & $\$ 14.73$ \\
\hline Ranch maintenance & Per head & $\$ 8.84$ & & $\$ 8.84$ & & $\$ 5.89$ \\
\hline Beef check-off & Per head & $\$ 1.00$ & & $\$ 1.00$ & & $\$ 0.00$ \\
\hline Import fees & Per head & $\$ 0.00$ & & $\$ 0.00$ & & $\$ 11.25$ \\
\hline Interest paid & Per head & $\$ 16.15$ & & $\$ 13.26$ & & $\$ 0.00$ \\
\hline Gross return & Per head & $\$ 543.00$ & & $\$ 464.32$ & & $\$ 464.32$ \\
\hline Total variable costs & Per head & $\$ 470.20$ & & $\$ 388.16$ & & $\$ 309.14$ \\
\hline Total fixed costs & Per head & $\$ 29.32$ & & $\$ 27.06$ & & $\$ 24.31$ \\
\hline Net income & Per head & $\$ 67.73$ & & $\$ 70.96$ & & $\$ 145.66$ \\
\hline
\end{tabular}

ish brought them to North America. Sometimes called scrub cattle, cracker cattle, or swamp cattle, they are well known for their horns, slower growth rates, durability, and recreational value. ${ }^{1}$ The horns that these cattle exhibit are favorites of the sport enthusiasts because they grow rapidly and have the configuration to sustain the pressures put on them. Because they do not gain weight as readily as most beef animals do, Corrientes have a longer career in the arena. Team ropers and steer wrestlers prefer cattle that are lighter and will continue to run straight down the arena after leaving the chute.

Although Corrientes are the choice of sport enthusiasts, they are not well suited for beef production because they do not gain weight as readily as Angus, Hereford, and the other beef breeds grown primarily for slaughter. However, prices for beef calves from 1967 through 2003 have shown little change in real terms, whereas prices for sport cattle rose every year from 1990 through 2003 (Fig. 1). Based on prices, ranchers may be wondering if turning to the leaner Corriente cattle is a good way to beef up their bottom line.

To provide a science-based answer to an agricultural production question, we addressed whether sport cattle produc-

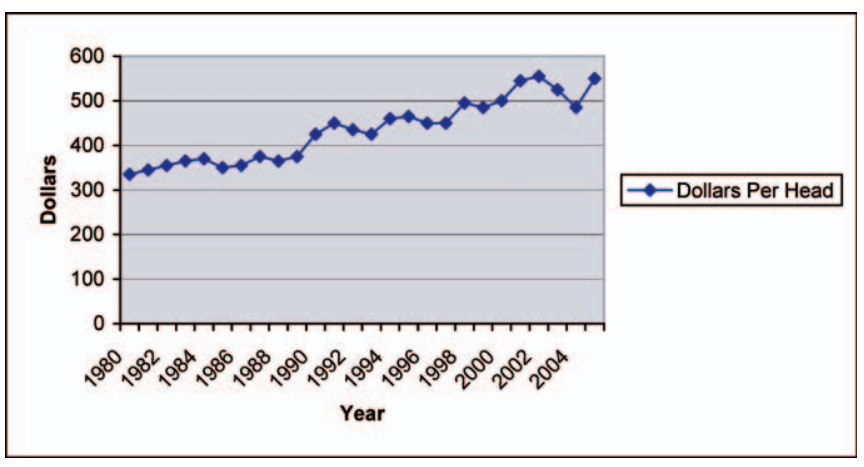

Figure 1. US sport cattle prices 1980-2005.

tion was a feasible alternative for cattle growers. To do so, we considered 3 alternatives exhibited in Table 1. The first is an extra-large yearling operation in New Mexico. This production unit has 350 purchased steer calves on it which are sold at an average weight of 750 pounds. The second is a 350head New Mexico Corriente operation with the purpose of raising cattle to 375 pounds for use in sporting events. The 
final scenario is a Corriente production unit in Mexico that crosses its sport cattle into the United States. Total costs, and returns on a per unit basis were estimated for each scenario for 1994-2003. ${ }^{7}$ We found that yearling steers raised in the United States for beef production were the least profitable at just over $\$ 50$ per unit in profit. The low profit margin is because of the fact that these producers have the highest production costs per unit. Cattle produced in the United States for sporting events returned just over $\$ 51$ per unit. These producers incurred less-variable costs in labor, operating, maintenance, and interest than those of the US beef producer. The most profitable of the 3 operations was the Corriente ranch in Mexico, where returns above total costs exceeded $\$ 116$ per animal. Costs in Mexico are significantly lower in regard to purchasing cattle, veterinary care, labor, and feed.

\section{Leasing Options}

Although producers of large rodeos and roping events usually own the cattle used in these events, those who host smaller events often lease the animals. A typical lease fee for a roping steer is $\$ 25$ per head per month. The person who is leasing the animal is responsible for its care and health. A standard leasing period is 6 months. This may turn out to be the more logical alternative for some timed-event enthusiasts.

\section{Conclusions}

Sport cattle may be a feasible economic option for some producers in the United States. The sports that use these animals have shown increasing participation over the past few years. The producers in Mexico have a financial advantage when competing with domestic producers of sport cattle.

Authors are Assistant Professor, New Mexico State University Range Impovement Task Force (Hawkes), Assistant Professor (Lillywhite), and Professor (Libbin), Department of Agricultural Economics and Agricultural Business, New Mexico State University, Las Cruces, NM 88003, jhawkes@murphie.nmsu.edu.

\section{References}

1. North American Corriente Association. 2004. North American Corriente Association. Available at: http://www. corrientecattle.org. Accessed 18 October 2006.

2. Findlay, J. May 2004. By the Numbers. SuperLooper Magazine: 12-13.

3. ESPN. 2004. Pro rodeo home page. Available at: http://sports. espn.go.com/prorodeo/news/story. Accessed November 2004.

4. Arnold, R.A. 2001 Micro economics. 5th ed. South Western College Publishing-Thomas Learning.

5. Bureau of Economic Analysis. Per capita income 2003. Available at: http://www.bea.gov/briefrm/percapin.htm. Accessed March 2004.

6. US Team Roping Championships. 2004. Available at: http:// www.ustrc.com. March 2004.

7. Hawkes, J. M., and J. D. Libbin. February 2004. Projected range livestock cost and return estimates for New Mexico, 2004. Range Improvement Task Force, New Mexico State University, Cooperative Extension Service. 